\title{
Julia Kristeva and the Ethics of Exile
}

\author{
Dawne McCance
}

\section{Julia Kristeva et une éthique de l'exile}

Un texte de Kristeva, 'My Memory's Hyperbole' (Ma mémoire hyperbole) sert de modèle pour les textes autobiographiques des femmes qui s'écartent du norme de 'raconter un vie' pour 'grapher l'auto.' L'autobiographie de Kristeva se présente au pluriel pour prendreses distances d'un sujet reférentiel, il se présente plutôt comme un sujet en procès dont la drame de se faire vivant en différése trace dans toutes ses mutations et ses divisions. McCance élabore la théorie Kristevan du sujet en procès dans le contexte des méditations sur une éthique de la transformation à fin de remplacer une éthique humaniste, perspective fonder sur un sujet stable. Étant donnéle rôle important que Kristeva attribue à la littérature dans cette éthique de la transformation, McCance élabore sa théorie par le biais de l'oeuvre de deux poètes canadiennes, Smaro Kamboureli et Lola Lemire Tostevin.

person (O.E.D.): (a mask used by a player, a character or personage acted (dramatis persona), one who plays or performs any part; in the general philosophical sense: a self-conscious or rational being

The mirror no longer exists in which a monolithic logos $-a$ 'monologic' - once appeared ... this passing beyond representation, this work which destroys it, has always been the 'other' of theological discourse, has always constituted theatrical space, in which the 'I' puts on the mask of equivocal laughter of sex-
Here I use 'person' to identify those entities that are self-conscious, rational and self-determining. Such a use of 'person' is important, for it will help to determine which entities exist that can act as we, that can know they exist and act, and which can, then, reflect upon their knowledge and action and take responsibility for it. This use of person arises in discussions of the existence of other minds 


\section{$24 \cdot$ Tessera}

ual excesses in order to mime the drama of his analysis, that is, of his death. From the Greek Menippean satire on to Lucan and Petronius, to the medieval carnival - a theatre with no stage and therefore with no audience and no performance, for everyone involved is his own author and actor, his ego and his alter ego - to Rabelais and Swift, to Joyce, Artaud and Bataille, the deathly laughter of this deconsecrated ' $I$ ' becomes stronger and clearer, more biting and effective. It destroys the monologic of representational literary discourse and sets the general scene for a kaleidoscopic and pluralist way of writing in which we see nothing, for it is the writing which sees us. ${ }^{1}$ and can be construed as an epistemological use of the term. The exploration of such epistemological issues (e.g. on what grounds can I know that an entity is a person?) requires rendering the definition of person as a concept as precisely as possible. Such precision will be an ontological quest to be clear about a category of reality.... One should note that interest in defining the concept of person is not just ontological or epistemological. One is not simply concerned with categorizing the entities that furniture the world. One is interested as well in the concept of person due to its role in ethical theory. Thus, in addition, one will be interested in identifying those entities that are self-conscious, rational, and self-determining, because they will, as well, be the moral agents of the universe. ${ }^{2}$

In 1984, Julia Kristeva wrote the essay, 'My Memory's Hyperbole,' for inclusion in an anthology of female autobiographies edited by Domna Stanton and titled The Female Autograph. ${ }^{3}$ Stanton explains in her Preface that she excised bio from autobiography in the volume's title in order to bracket the traditional emphasis on autobiography as the recounting of 'a life,' with that notion's facile presumption of referentiality, and to suggest that the women's writing in this collection does not so much narrate as 'graph the auto. ${ }^{4}$ Kristeva's essay is in keeping with this non-referential understanding of the self, since it is offered as hyperbole, not to be taken literally, and since it is written in the first person plural, a form which she adopts in place of the objective and authorial ' $\mathrm{I}$ '. 'My Memory's Hyperbole' traces through the evolution of the so-called Tel Quel group in Paris, from the time of Kristeva's arrival late in 1965, until 1974, when the Tel Quel journal 
folded. The essay does provide a scheme, then, an outline of intellectual and political developments, but written as the auto(bio)graphy of a 'we' that remains hyperbolic. As Domna Stanton describes it, Kristeva's essay 'confounds generic and genderic boundaries' as it discusses intellectual and political movements in Paris, 'analyzing the various scenes, acts, and dramatis personae not merely as a critical observer, but undeniably as a major protagonist. ${ }^{5}$ Against the background of political and intellectual revolution, Kristeva's memoir is written as a history which analyses its self, that self's ongoing mutations and divisions. The result is not the narration of a stable and unified subject, but the drama of a hyperbolic subject-in-the-making, ${ }^{6}$ a subject which 'is alive only if it is never the same. ${ }^{7}$

In the following paper, I attempt to outline Kristeva's theory of this subject-in-process in the context of her reflections on ethics. Although little critical attention has been given to the point, the status of the subject in relation to ethics is an important issue in all of her writing. She argues repeatedly against the definition of ethics as a prescriptive moralism which legitimizes the static humanist subject, and in favour of one which views the transformation of this subject as the contemporary ethical imperative. Kristeva maintains that literature plays an important role in this ethical transformation, a point which I will explore in relation to two Canadian women writers, Lola Lemire Tostevin and Smaro Kamboureli. In the conclusion of the paper, I comment on Kristeva's analysis of the women's movement in regard to her suggested reformulation of ethics.

\section{1. s'exiler: to go into exile; to expatriate one self}

L'exil coupe les liens, et jusqu'aux plus profonds, ceux du Sens, ceux qui nous attachent à la croyance queça-la vie-a Un Sens, garanti par un père mort. ${ }^{8}$

In her Preface to Desire In Language, Kristeva writes of 'the necessity of adopting a stance involving otherness, distance, even limitation' as 'the only guarantee of ethics' in a world of technological rationality. ${ }^{9}$ Such a stance requires that a subject recognizes itself as double, as made up of an other-self, and as subject of a discourse which arises from another discourse. ${ }^{10}$ It is, therefore, not the theoretical stance of a monological subject: a subject who sees its self as one, a 
conscious unity, and as such, as master of its own discourse. Kristeva refers to monological theory as a 'zero-one' system, that is, a system in which a univocal subject conceives of language as a unidimensional structure which $\mathrm{s} /$ he uses to define all terms as either true or false, either same or different. ${ }^{11}$ Because monological discourse sets up this either / or law of the excluded middle, it functions as prohibition or closure. ${ }^{12}$ The monological subject hems us in (suturé) to a predetermined meaning and coherence, disallowing what is heterogenous to his / her system, closing off what is other in language.

Kristeva refers to this monological prohibition as a 'moral code' precisely because it has long governed western morality. ${ }^{13}$ Particularly since the seventeenth century, and the emergence of the modern subject as both the Cartesian cogito and the subject of individual rights, western morality has been based on the idea that conscious unity gives the moral subject control or mastery, and thereby makes him free. ${ }^{14}$ According to John Locke, for example, the term person applies only to a conscious self, whose rights (freedoms) are grounded in his conscious rationality. ${ }^{15}$ Not the least of these rights, for Locke, is the right to private property, which includes proprictary ownership and control of one's body. ${ }^{16}$ There is no departure from this logic in contemporary moral philosophy's definition of the person as 'an entity that has the (actual, not merely potential) capacity for consciousness, complex and sophisticated perception, rationality, self-awareness, and self-motivated behaviour', with the attendant assertion that only such persons are possessors of full moral rights. ${ }^{17}$ In contemporary moral philosophy, rights are understood as claims, such that 'To have a right to something is to be in a position, morally or legally, to demand that thing as properly one's own.' ${ }^{18}$ And the preeminent moral right, of course, is property, understood as privacy, autonomy or self-determination, and as granting ownership and control of one's body. According to philosopher Judith Jarvis Thomson, this right to privacy applies particularly to contemporary women, who are now demanding their full rights to choice and control: Women have said again and again, 'This body is my body! and they have reason to feel angry, reason to feel that it has been like shouting into the wind ... if a human being has any just, prior claim to anything at all, he has a just, prior claim to his own body. ${ }^{\prime 19}$

Kristeva writes that anyone who ascribes to this monological theory ought 'to pause and query the ethics of his own discourse. ${ }^{20}$ That 
the comment appears in an essay on 'The Ethics of Linguistics,' indicates that, for her, the subject of ethics is not confined to a specialized discipline of philosophy or theology. All discourse has an ethical function, and all monological discourse functions coercively, to reinforce an unethical moral code. ${ }^{21}$ Kristeva's analysis parallels that of other Tel Quel writers during the 1960's, notably Jacques Derrida and Michel Foucault, insofar as it locates the contemporary problem of power in the subject's constitution of itself as a conscious and private unity. ${ }^{22}$ According to these writers, the constitution of the subject in this form is the principal support of modern capitalist-technological society, where the most profound form of techne is not external controls or instruments, but a subject-based discursive rationality. Crucial to this kind of power is a disciplinary fixation on the proprietary body, which becomes as much an object for the modern subject, as does nature, language, and all that is not-same, not-conscious, notperson. ${ }^{23}$ For Kristeva, what is particularly dangerous, and unethical, about this subject is that it masks its violent separations and divisions. For the modern monological subject, coercion functions under the cover of unity, equality, freedom, and 'natural' language. ${ }^{24}$

Kristeva's early essays, many of which are published in Séméiotiké (1969), attempt to move literary criticism and stucturalist linguistics from monological theory to what she calls the 'zero-two' practice of poetic language. ${ }^{25}$ For example, 'Pour une sémiologie des paragrammes' uses Ferdinand de Saussure's Anagrammes to develop the notion of a paragrammatical text: the text as an interrelation of texts; a multi-faceted juncture of meanings and codes. ${ }^{26}$ The goal is to 'dynamize' structure through a theory of the text as production and of language 'as a free play, forever without closure.' ${ }^{27}$ A semiotics based on this model would emphasize the dynamics of production over the actual product' and therefore the otherness (alterité) of what it studies, rather than focusing on a reified and representable object. ${ }^{28}$ At the same time, since the text is inseparable from subjectivity, shifting toward the other scene of the text's production implies a similar displacement and 'spatialization' of the writing subject, and suggests the need for a theory of this subject as itself a productive activity in language. In the field of poetic language, Kristeva explains, 'the unit'one' (definition, 'truth') does not exist': every poetic paragram is a double and the notion of a 'person-subject of writing' gives way to that of a self which is both ' $\mathrm{I}$ ' and an other. ${ }^{29}$ 
In this poetic 'doubling' of the subject and language, Kristeva identifies what she calls the 'ethical dimension' of Roman Jakobson's work. ${ }^{30}$ Jakobson's reading of the futurist poets is an 'opening' of monological theory to the 'other of the linguistic and / or social contract', thereby enabling the speaking subject 'to shift the limits of its enclosure.' By giving voice to the rhythm inscribed in Mayakovsky's poetry, Jakobson allows us to hear the 'silent causality and ethics' inherent in poetic language. The essential point for Kristeva is that language is double: both rhythm and structure, both struggle and law; and that the subject is never either monological reason or asymbolic rhythm, but a subject who both formulates meaning and questions those formulations in an unending dialogical process. ${ }^{31}$ In her essays on Mikhail Bakhtin, Kristeva again links this dialogical theory to the development of what she calls an 'ambivalent ethics,' where the private author-owner gives way to an older understanding of the person as dramatis persona, a player whose drama-struggle is in language. ${ }^{32}$

A Bakhtinian ethics is 'ambivalent' because it is simultaneously one and the other, never individual, and never closed off from the body. ${ }^{33}$ In that it opens to the depth of the subject, it is, for Kristeva, 'quasi-psychological,', 34 and a foreshadowing of what I am calling her psychoanalytic 'ethics of exile.' Kristeva's psychoanalytic theory emphasizes that for every subject in language there is a heterogeneousness to meaning and signification. For her to refer to signification as significance, then, is not simply a way of introducing dynamism (process) into the traditional notion of representation. ${ }^{35}$ The goal is to open representation to a pre- or translinguistic modality of psychic inscription which she calls the 'semiotic' (le sémiotique), from the Greek sémeion, mark, trace of the unconscious other. The 'semiotic' is distinct from, and supplementary to, the 'symbolic' (le symbolique), language as representation, meaning, sign. ${ }^{36}$ Although the two modalities can be recombined in different ways to constitute different types of discourse, language as social practice necessarily presupposes both the 'semiotic' and the 'symbolic'. I think the point is crucial. There is, for Kristeva, no possibility of a monological subject who could completely close off the unconscious to secure unity and certainty in language, and neither is there any possibility of a meaningful language outside the pro-positioning of a conscious subjectivity. For her, the subject in language exists in a permanent state of division between the semiotic and symbolic, a division which univocal ratio- 
nal discourse attempts to hide. While it is the case, for her, that there must be separation (of subject from object) and division (of conscious from unconscious) in order for a subject to posit meaning in language, the subject in language must nevertheless remain in a hyperbolicsujet en procès: a subject-in-process / on trial. This subject becomes itself as an unfinished production in language. It is thus a divided subject, placed on trial by its own otherness, a subject which posits its thesis as undecidable process between semiotic and symbolic. ${ }^{37}$

In Revolution in Poetic Language, Kristeva argues that the reformulation of ethics today cannot be undertaken apart from a perspective which recognizes this process / trial of the subject in language. ${ }^{38}$ That is, unless it is to be an extension of monological morality, ethics cannot be stated as scientific truth about the nature of the person, sexuality, the Good. For Kristeva, this kind of moralism suppresses the ethical function, in complicity with a necessarily oppressive System. ${ }^{39}$ In her words: "The ethical cannot be stated, instead it is practiced to the point of loss, and the text is one of the most accomplished examples of such a practice'. ${ }^{40}$ But 'the text fulfills its ethical function only when it pluralizes, pulverizes, 'musicates" meaning; that is, only when it opens to an otherness which puts monological meaning on trial ('reaching out to the other, the ethical' ${ }^{41}$ ). The subject of such an ethics cannot elevate him / herself to the philosopher's position of privilege (privilege: privus: private + lex: law). In Kristeva's understanding, there is no fixed position for a subject above or outside of language. The subject's only place is in language, and therefore, its position (identity, meaning) can never be fixed. Kristeva's subject is one who wanders: 'an outcast, a lost soul (égaré),' ${ }^{42}$ a subject for whom the question of identity is not one of being, but of place: 'Where am I?' rather than 'Who am I?' For the space with which the outcast, the excluded is preoccupied, is never one; it is neither homogenous nor totalisable, but essentially divisible, pliable, catastrophic.' ${ }^{43}$

\section{2. 'An Exile who asks, 'Where?' ${ }^{44}$}

The 'where?' of a self's identity is the recurring question of Smaro Kamboureli's in the second person ('It hurts not to know where home is.'; 'i ask her where my polis is.'; 'you seem not to know where you are.'). ${ }^{45}$ In this female autographic text, the writer traces the history of her self as she emigrates from Greece through the United States to Canada. The book does not conform to the monological definition of a 


\section{$30 \cdot$ Tessera}

unified genre, since it is a 'permutation of texts, ${ }^{46}$ or what Helen Buss describes as a 'mélange of forms - poetry, anecdotes, quotations, aphorisms, discussions, jokes, dreams, memories, diary entries and narrative transitions ${ }^{\prime}{ }^{47}$ As John Donlan suggests, this plurality of forms and styles 'enacts' an understanding of the self as 'fragmented, multiple and elusive' and it suits the book's theme of the search for self through the production and examination of texts, 'those writings ... we generate ... which are us and not-us. ${ }^{48}$ In this auto(bio)graphy, exile is not simply a condition of dislocation from place and language, but of the dislocating place of language ('Not place and language. But place of language.'(11)), the self's splitting and shifting in language, such that Nobody can / ask where / exactly / it lies'(60).

On the opening page of the book, Kamboureli tells us that before she left Greece, she burned her previous writing - a diary, the beginnings of an aborted novel, pages of prose poems - an act which 'seemed to be a way of erasing personal traces, traces of language, whose absence could set me free and open to receive what is on the other side of the ocean.' (7) The ritual burning was, she says, 'a gesture that defined me through language.'(7) For this self who is defined through language, '(i)mmigration is a form of abjection'(8), such that movement into a second language is experienced as erasure of her former self: "To live bathed in a language other than my mother tongue, I have to partially drown the being that was nourished by the mother tongue.'(10) In this sense, in the second person is a meditation on exile as division of self, and displacement of a former self, who becomes the writer's other-self, the other whom she addresses, and by whom she is addressed in this dialogical discourse ('writing as trace of a dialogue with oneself (with another) ${ }^{\prime 49}$ ):

are we getting even

now is that what it is you have a greek accent and $i$ have an english accent so we're told(35)

you can't spit me out

I am the image of your life locked between the folded wings of a butterfly (52) 


\section{Julia Kristeva and the Ethics of Exile 31}

As the book develops, the authorial ' $\mathrm{I}$ ' undergoes further fragmentation, becoming more polyphonic and elusive, more of a stranger to monological language. Something can be said 'in person' here without issuing from the authorial form of the first person, but from the second and third persons, indeed from the various forms (genders, genres) that a multiple ' $\mathrm{I}$ ' can occupy, and that we hear in a plurality of voices ('i. me. you. the other.'(79);

$$
\begin{aligned}
& \text { i play } \\
& \text { you play } \\
& \text { s/he plays } \\
& \text { it plays } \\
& \text { we play } \\
& \text { you play } \\
& \text { they play }
\end{aligned}
$$

It is this plurivocality, this otherness, which causes a trial of the subject in language. Without strictly wanting to recognize her other ('Why am I looking for sameness?' (41); 'it is siesta time. keep silent. lie down. dream, if you wish.'(36); 'you haven't visited me today / but $i^{\prime} m$ not lonely / $i$ think of my contentment as my revenge.'(53), Kamboureli never ignores this other for a minute, never settles down as a unified subject:

\section{but you are not a memory. you}

are the act of remembering itself. you are the other ... you know no temporal boundaries ... no spatial borders.... only a huge act of will can put a stop to your spiralling presence around me. I have, again, to find my way through the passages you open for me. i'm after you, too; but not with your own persistence. $i$ was there then, yes. but i'm here now. mark these words. (43)

This borderline condition 'on the edge of two languages, on the edge of two selves named and constructed by language' (11) is both unsettling ('when i get closer to you i tremble with confusion. / $i$ 'm not sure whether $i$ want to know where you live / so that $i$ can run away from you, or whether i want / to meet you, to blend with your historic present.'(52), and liberating, a release from monologism into 
jouissance: "The self becomes a being of multiple meanings and jouissance and many little deaths.' (11). Near the end of the book is a journal entry which recalls a serial dream, and which perhaps sums up this self's process / trial in language:

In a maze all night. Ek-static, lost in the surprise of motion, constant movement toward a polis. When I reached it, it was all in ruins.(76)

Lola Lemire Tostevin, in Color of Her Speech asks 'where / and with what words / do we begin?' ${ }^{50}$ Like Kamboureli, Tostevin writes of the self-alienation which results from the 'un-speaking' of her mother tongue, in this case French, by the dominant English language. In Tostevin's poetry, this 'alien condition' stems not only from the displacement of her French mother tongue, but from the excision of woman's tongue by a male monological system. In the either/or (male/notmale, person/not-person) terms of this monological system, woman is either silenced-excluded as 'a phenomenon of some outside world, ${ }^{51}$
once
the mouth
stood empty
it was easy
to introduce
your difference

or, she is allowed to come into the system, but at the price of effacing sexual difference, 'since the Cartesian cogito is related to a subject which bears no sexual identity and since its clarity of mind barely acknowledges the existence of a body or an unconscious working from an affective and sensory system.' ${ }^{52}$ In entering the monological system as a unified person-subject of language, woman

becomes one

half

Tostevin neither identifies with the unitary subject nor suggests 
Julia Kristeva and the Ethics of Exile $\cdot 33$

that women can withdraw into an asymbolic femininity. For her, a female self-identity can only be produced in process in language. Color of Her Speech: 'it takes / a different tongue / to penetrate / a different depth.' Tostevin's writer-self wanders from one side to 'the other' of patriarchal language tracing a path of jouissance:

mother

memory tongue

towards with -

drawing

\section{retracing}

retrieving

à la source

à la dérive

adrift

driving along the shore

of the St Lawrence

on a sunny March morning

babbling french with Jean Marcel

after all these years

river

frozen

fixed

fleuve

flows back

to vague

memory ${ }^{53}$

One of the ways in which Tostevin's poetry opens to a new depth, and thereby to new possibilities, is through her exploration of rhythm. In her poetry, to use Kristeva's words, 'the sounds of language are more than phonemes. ${ }^{54}$ They inscribe an unconscious dimension which is unacknowledged by univocal language. In 'Gyno-Text' 


\section{Tessera}

(Color of Her Speech) for example, Tostevin uses rhythm to reconnect language with the female body which has been muted and repressed by the monological system, and in the process, she resignifies female sexuality as multiple, fluid, and relational: ${ }^{55}$

$\begin{array}{lll}\text { oral } & \text { breath } & \text { voice } \\ \text { pit } & \text { of } & \text { boxed } \\ \text { spits } & \text { bone } & \text { in } \\ \text { yolk } & \text { by } & \text { ears } \\ \text { spins } & \text { bone } & \text { echo } \\ \text { spine } & \text { body's } & \text { deeper } \\ \text { first } & \text { pounding } & \\ \text { embryo } & \text { articulation } & \text { tympa } \\ \text { rolls } & \text { arteriole } & \text { tym } \\ \text { like } & \text { first } & \text { panic } \\ \text { a } & \text { vowel } & \text { rhythm } \\ \text { scroll } & \text { of a } \\ & \text { heart } & \\ \text { some } & & \text { w)here }\end{array}$

Tostevin's writing here may relate intertextually to Kristeva's 'Stabat Mater,' that typographically fragmented essay in which the main text is accompanied by rhythmic, poetic inserts which use allitera tive patterns and semantic dislocations in an effort to join the written word to its underlying body. ${ }^{56}$ Certainly, both 'Stabat Mater' and 'Gyno-Text' situate the writing subject on what Kristeva calls 'the place of the scar' or 'wound,' the place which Tostevin refers to in Color of Her Speech as the 'cicatrice': the borderline between conscious and unconscious. ${ }^{57}$ Here, truth no longer has reference to a subject, or object, identifiable outside of language, but to a poetic practice which opens monological meaning and allows for the possibility of renewal.

\section{3. 'Where can be our place in the symbolic contract?' 58}

Kristeva argues that a dialogical subject-in-process cannot take (a) place inside the social contract, that its 'only inhabitable place-locus - is language. ${ }^{59}$ This is the crux of her criticism of the kind of feminism which represents a 'logic of identification' with the patriarchal system, its conscious subject and his proprietary rights. ${ }^{60}$ While 
acknowledging the accomplishments that this kind of feminism has achieved, she considers it nonetheless a strategy which conforms to the seventeenth century ideal of homo rationalis, and therefore, which cannot succeed in providing for fundamental and long-term change. Her writing always begins from the same basic premise: '... there can be no socio-political transformation without a transformation of subjects. ${ }^{61}$ On the other hand, to say that women must break with the subject of the social contract does not mean, for Kristeva, that they are exiled to a foreign land outside patriarchal society, 'an a-topia, a place outside the law.' ${ }^{62}$ She argues that the kind of utopian feminism which dreams of a countersociety founded on the qualitative difference of women from men, and 'imagined as harmonious, without prohibitions, free and fulfilling,' constitutes an inverted sexism which only reiterates the monological rule of ONE. ${ }^{63}$

Etymologically, Kristeva points out, analysis means dissolution: to unbind, dissolve, cut, divide, dislocate, lose ${ }^{64}$ She emphasizes that psychoanalysis does not liberate us into self-completion and wholeness. Its task, instead, is to record the crisis of unifying interpretations. Focusing her critique on the unitary subject, Kristeva takes the analysis of contemporary technological power 'into the very interior of every identity,' and to the 'cutting edge' (wound, cicatrice) of the necessary divisions between 'self' and 'other' which characterizes the construction of an identity in language. The analysis is undertaken in order to bring out 'along with the singularity of each person, and, even more, along with the multiplicity of every person's possible identifications,' the 'relativity' of his or her identity / meaning in language. ${ }^{65}$ For Kristeva, this is the ethical meaning of psychoanalysis, and the significance it might have for a fledgling feminist ethics. For her, any person aware of the fact that his or her order is divisive, and potentially violent, will emphasize 'the responsibility which all ... face of putting ... fluidity into play against the threats of death which are unavoidable whenever an inside and an outside, a self and an other, one group and another, are constituted. ${ }^{66}$ The goal is to develop kinds of thinking, writing and teaching, which leave openings for the other. In undecidability lie the psychoanalyst's desireand ethics. ${ }^{67}$ 


\section{$36 \cdot$ Tessera}

\section{Notes}

1. Julia Kristeva, 'The ruin of a poetics,' in Stephen Bann and Joseph Boldt, eds., Russian Formalism (Edinburgh: Scottish Academic Press, 1973), p. 115.

2. H. Tristram Engelhardt, 'Viability and the Use of the Fetus,' in William Bondeson, H.T. Engelhardt, Stuart Spicker, Daniel Winship, eds., Abortion and the Status of the Fetus (Dordrecht, Boston, Lancaster: D. Reidel, 1983), pp. 184-5.

3. Kristeva, 'My Memory's Hyperbole,' in Domna Stanton, ed., The Female Autograph (Chicago \& London: The University of Chicago Press, 1987), pp. 219-235. The essays originally appeared in The Female Autograph volume 12-13 of the New York Literary Forum, 1984.

4. Stanton, 'Preface, 'The Female Autograph, pp. vii-viii.

5. Ibid., p.x.

6. See 'Oscillation du 'pouvoir' au 'refus', translated by Marilyn August in Elaine Marks \& Isabelle de Courtivron, eds., New French Feminisms (New York: Schocken, 1980), p. 167, where Kristeva uses this expression in reference to le sujet en procès.

7. Kristeva, 'My Memory's Hyperbole,' p. 220.

8. Kristeva, 'Un nouveau type d'intellectuel: le dissident,' Tel Quel 74 (Winter 1977), p.7.

9. Desire In Language, p.ix.

10. 'The ruin of a poetics,' p. 109.

11. See for example, 'Word, Dialogue, and Novel,' in Desire In Language, pp. 64-91.

12. 'The Bounded Text,' Desire In Language, pp. 42-3; see also, Evelyn H. Zepp, The Criticism of Julia Kristeva: A New Mode of Critical Thought,' in Romantic Review 73:1 January 1982), pp. 80-97.

13. See Kristeva, 'Approaching Abjection,' in Powers of Horror: An Essay on Abjection, trans. Leon Roudiez (New York: Columbia University Press, 1982), p. 29.

14. Ibid.

15. For Locke's definition of person, see An Essay on Human Understanding, ed., A.D. Woozley (New York: New American Library, 1974), pp. 206-220. For his explication of individual rights, see Second Treatise of Government, ed.C.B. Macpherson (Indianapolis, Indiana: Hackett Publishing Co., 1980).

16. Locke, Second Treatise,e.g., p. 27:'... though the things of nature are given in common, yet man, by being master of himself, and proprietor of his own person ... [has] in himself the great foundation of property.'

17. Mary Anne Warren, 'Can The Fetus Be An Organ Farm?,' Cases in Bioethics, ed. Carol Levine and Robert Veatch (New York: The Hastings Center Institute of Society, Ethics and the Life Sciences, 1982), p. 9; see also, H. Tristram Engelhardt, 'Medicine and the Concept of Person,' Ethical Issues in Death and Dying, ed. Tom Beauchamp and Seymour Perlin (Englewood Cliffs, New Jersey: Prentice-Hall, 1978), pp. 94-101; Michael Tooley, Abortion and Infanticide (London: Oxford University Press, 1983); David Smith, 'Who Counts?', Journal of Religious Ethics 12:2 (1984), pp. 240-255. 
18. Joel Fineberg, 'Rights,' in Warren T. Reich, ed., Encyclopedia of Bioethics (New York: The Free Press, 1978), p. 1511.

19. Judith Jarvis Thomson, 'A Defense of Abortion,' in Tom Beauchamp and LeRoy Walters, Contemporary Issues In Bioethics (Belmont, California: Wadsworth Pub. Co., 1982), p. 234. The article appeared originally in Philosophy and Public Affairs 1:1 (1971), pp. 47-66.

20. 'The Ethics of Linguistics,' in Desire In Language, p. 23.

21. As monological theory, she includes Cartesian-Lockean-Kantian philosophy, the structuralist linguistics of which she is critical in this essay, and also all literary discourse which is concerned with self-identity and representation, including 'realist description, definition of 'personality,' 'character' creation, and 'subject' development - all are descriptive narrative elements belonging to the $0-1$ interval and are thus monological.' See 'Word, Dialogue, and Novel,' p. 70.

22. See for example, Leon Roudiez, 'Twelve Points from Tel Quel,' Esprit Createur 14:4 (Winter 1974), pp. 291-303; Roudiez, French Fiction Today (New Brunswick: New Jersey: Rutgers University Press, 1972), pp. 369-387; Kristeva, 'My Memory's Hyperbole.'

23. See Francis Barker, The Tremulous Private Body: Essays On Subjection (London and New York: Methuen, 1984).

24. See for example Kristeva, 'Women's Time,' trans. Alice Jardine and Harry Blake, Signs 7:1 (1981); 'The Ethics of Linguistics,' pp. 23-4.

25. Kristeva uses the term 'poetic language' in the Russian formalist sense, including poetry and prose. She uses the expression 'zero-two' in reference to writing which is dialogical or double. According to 'My Memory's Hyperbole' p. 224, 'structuralism was already accepted knowledge' for her when she arrived in Paris, and from the outset 'our task was to take this acquired knowledge and immediately do something else', i.e. move structuralism from a 'zero-one' to a 'zero-two' or 'poetic' logic. See also, Jean-Paul Enthoven, interviewer, 'Julia Kristeva: à quoi servent les intellectuels?,' Le Nouvel Observateur (June 26, 1977), p. 99.

26. 'Pour une sémiologie des paragrammes,' Séméiotiké: Recherches pour une sémanalyse (Paris: Seuil, 1969), pp. 174-207; see also, 'My Memory's Hyperbole,' p. 225; Mary Ann Caws, 'Tel Quel: Text and Revolution,' Diacritics (Spring 1973), p. 81.

27. Kristeva, 'From One Identity To An Other,' in Desire In Language, p. 128.

28. Kristeva, 'La sémiotique, science critique et / ou critique de la science,' in Séméiotiké, pp. 39-40.

29. Kristeva, 'Word, Dialogue, and Novel,' in Desire In Language, pp. 68-9. This essay was also originally published in Séméiotiké.

30. See for this, 'The Ethics of Linguistics,' pp. 26-35.

31. Ibid; see also, 'La sémiotique, science critique et / ou critique de la science.'

32. See 'Word, Dialogue, and Novel,' and 'The ruin of a poetics.' See also, 'The Bounded Text,' where Kristeva situates Antoine de La Sale's Jehan de Saintré at the threshold of the modern age, when the medieval understanding of person as actor and author is yielding to the modern notion of univocal 


\section{$38 \cdot$ Tessera}

author who is authority-owner of the product-work.

33. For a fuller development of Bakhtin's philosophy of 'ambivalent wholeness,' see Mikhail Bakhtin, Rabelais and His World, trans. Hélène Iswolsky (Bloomington: Indiana University Press, 1984), pp. 59-195.

34. 'The ruin of a poetics,' p. 110.

35. Kristeva, In the Beginning Was Love: Psychoanalysis and Faith, trans. Arthur Goldhammer (New York: Columbia University Press, 1987), pp. 4-5.

36. See for example, 'From One Identity To An Other,' pp. 133-4.

37. 'From One Identity To An Other,' p. 135. In psychoanalytic theory, the self's divisions-separations begin at the mirror stage when the child separates its self from a specular object, as prototype of the separation of the world into subjects and objects. It continues with the child's entry into language: the vesting of the specular ' $I$ ' with positionality in signification, which causes a division of conscious from unconscious.

38. Kristeva, Revolution in Poetic Language, trans. Margaret Waller (New York: Columbia University Press, 1984), p.233.

39. Ibid., p. 234.

40. Ibid., p. 233.

41. Kristeva, 'Stabat Mater,' in Tales of Love, trans. Leon Roudiez (New York: Columbia University Press, 1987), pp. 259-260.

42. 'Approaching Abjection,' pp. 130-1.

43. Ibid.

44. Kristeva, 'Approaching Abjection,' p. 8.

45. Smaro Kamboureli, in the second person (Edmonton, Alberta: Longspoon Press, 1985), p. 27; p. 77; p. 78. Page references for further citations will be given in the text.

46. 'The Bounded Text,' p. 36: this is Kristeva's definition of 'intertext.'

47. Helen Buss, 'Canadian Women's Autobiography,' in Shirley Neuman and Smaro Kamboureli, eds., A Mazing Space: Writing Canadian Women Writing (Edmonton, Alberta: Longspoon / Newest, 1986), pp. 156-7.

48. John Donlan, 'Communication Deluxe,' Contemporary Verse 2 10:3 (Spring 1987), p. 58.

49. 'Word, Dialogue, and Novel,' p. 74.

50. Lola Lemire Tostevin, Color of Her Speech (Toronto: The Coach House Press, 1982), unpaginated.

51. Tostevin, Breaking the hold on the story: the feminine economy of language,' in A Mazing Space, pp. 386.

52. Ibid., p. 388 .

53. Color of Her Speech.

54. Kristeva, 'Phonetics, Phonology and Impulsional Bases,' trans. Philip Lewis, Diacritics (Fall 1974), p. 34.

55. See also, Lola Lemire Tostevin, 'sophie (Toronto: The Coach House Press, 1988), p. 74, for an example of Tostevin's use of rhythm to 'musicate' language: to open 'naming' to multiple displacements and condensations of meaning.

56. The essay was originally published as 'Héréthique de l'amour,' in Tel Quel 


\section{Julia Kristeva and the Ethics of Exile · 39}

74 (Winter 1977), pp. 30-49. It is translated in Tales of Love, pp. 234-263.

57. See 'Julia Kristeva in Conversation with Rosalind Coward,' in Desire (London: Institute of Contemporary Arts, 1984), p. 24, where Kristeva explains that she presented 'Stabat Mater' in two kinds of type face because she wanted 'to give an impression of a sort of wound, a scar' with the writer 'posited precisely on this place of the scar.' On the opening page of Color of Her Speech, Tostevin writes: 'mais jamais / on se défait / de nos cicatrices / Majuscules'

58. Kristeva, 'Women's Time,' p. 23.

59. Ibid., p. 131.

60. 'Women's Time,' pp. 19-35.

61. 'La Femme, ce n'est jamais ça,' trans. by Marilyn August as 'Women Can Never Be Defined,' in New French Feminisms, p. 141.

62. Ibid., p. 27.

63. 'Women's Time,' pp. 18-35.

64. Psycholanalysis and Faith, p.7.

65. 'Women's Time,' pp. 34-5.

66. Ibid., p. 35.

67. Kristeva, 'Within the Microcosm of "The Talking Cure,"' in Joseph Smith and William Kerrigan, eds., Interpreting Lacan (New Haven and London: Yale University Press, 1983), p. 38. 